STUDIA PRAWNO-EKONOMICZNE, t. CIV, 2017

PL ISSN 0081-6841; e-ISSN 2450-8179 $\quad$ s. 235-254

DOI: 10.26485/SPE/2017/104/13

Jolanta M. CIAK*

Grażyna VOSS**

\title{
ROLA AUDYTU WEWNĘTRZNEGO W SEKTORZE PUBLICZNYM I PRYWATNYM - WYNIKI BADAŃ W ZAKRESIE PROBLEMÓW WDRAŻANIA I KORZYŚCI Z WYKORZYSTANIA AUDYTU WEWNĘTRZNEGO
}

\begin{abstract}
(Streszczenie)
Audyt wewnętrzny jest działalnością niezależną i obiektywną, której celem jest przysporzenie wartości i usprawnienie działalności operacyjnej. Jego rola sprowadza się do systematycznej i dokonywanej w uporządkowany sposób oceny procesów zarządzania ryzykiem, kontroli i ładu organizacyjnego. Efektem końcowym powinna być poprawa ich działania. Treść artykułu dotyczy pierwszej części badań nad funkcjonowaniem audytu wewnętrznego w wybranych jednostkach sektora finansów publicznych (jsfp) oraz jednostkach zaliczanych do największych w Polsce spółek kapitałowych.

Celem artykułu jest określenie czynników determinujących wdrożenie procedur audytu wewnętrznego oraz różnic dotyczących wdrożenia i wykorzystania audytu w jednostkach sektora finansów publicznych i sektora prywatnego.

Wyniki przeprowadzonego badania w zakresie wdrażania i funkcjonowania audytu wewnętrznego w wybranych jednostkach wykazały, że organizacja i działalność audytu w większości przypadków była zgodna z przepisami prawa, a przyjęte rozwiązania umożliwiały niezależność działań audytorom. Badane jednostki były i są zainteresowane instytucją audytu wewnętrznego. Ich zdaniem realizacja i wdrożenie wydanych przez audytora rekomendacji poprawia skuteczność ich działań, a przeprowadzanie czynności sprawdzających stan realizacji zaleceń przez audytora wskazuje na trafność jego spostrzeżeń. Jednakże ankietowani wskazywali też w niektórych przypadkach na słabą skuteczność i efektywność audytu.
\end{abstract}

Słowa kluczowe: audyt wewnętrzny; jednostki sektora finansów publicznych; kontrola wewnętrzna Klasyfikacja JEL: H83

* Dr hab. prof. nadzw. Wyższa Szkoła Bankowa w Toruniu, Katedra Finansów i Rachunkowości; e-mail: jolanta.ciak@wsb.torun.pl

** Dr, Uniwersytet Technologiczno-Przyrodniczy w Bydgoszczy, Katedra Organizacji i Zarządzania; e-mail: gvoss@wp.pl 


\section{Wstęp}

W warunkach globalizacji kontrola wewnętrzna nie jest w stanie zapewnić sprawnego działania. Dlatego niezbędne staje się usprawnianie funkcjonowania jednostek we wszystkich obszarach jej działalności oraz identyfikacja i podjęcie działań mających na celu ograniczenie ponoszonego ryzyka. W literaturze wskazuje się, iż w odróżnieniu od kontroli wewnętrznej audyt wewnętrzny ukierunkowany jest na zapobieganie różnego rodzaju ryzyka. Nie ogranicza się jedynie do porównania stanu faktycznego ze stanem pożądanym, ale ma obowiązek rekomendowania działań zmierzających do poprawienia funkcjonowania badanego obszaru czy systemu. W związku z korzyściami, jakie niesie wdrożenie audytu, kierownik jednostki może zagwarantować jej poprawne funkcjonowanie. Jednak obszar obowiązywania procedur audytu i ocena korzyści wynikających z jego wdrożenia nie są tak samo postrzegane przez wszystkie podmioty.

Celem artykułu jest określenie czynników determinujących wdrożenie procedur audytu wewnętrznego oraz różnic dotyczących wdrożenia i wykorzystania audytu w jednostkach sektora finansów publicznych i sektora prywatnego. W artykule zostanie przedstawiony i omówiony audyt wewnętrzny jako instrument usprawniający zarządzanie jednostką oraz zaprezentowane zostaną wyniki badań przeprowadzonych w wybranych jednostkach sektora finansów publicznych oraz największych w Polsce spółek kapitałowych; zwrócenie uwagi na problemy związane $\mathrm{z}$ wdrażaniem audytu i możliwe korzyści z jego wykorzystania w badanych podmiotach. Celem artykułu jest odpowiedź na następujące pytania badawcze:

- Jaką rolę pełni współcześnie audyt wewnętrzny?

- Czy istnieją problemy z jego wdrożeniem w praktyce?

- Jakie korzyści przynosi i może przynieść prawidłowo funkcjonujący audyt wewnętrzny?

\section{Istota i znaczenie audytu wewnętrznego}

Historia audytu sięga czasów Mezopotamii, skąd pochodzą pierwsze dokumenty potwierdzające weryfikacje danych przez audytorów ${ }^{1}$. Nie jest to jedyny kraj z czasów starożytnych, w którym wykorzystywano ówcześnie znane procedury audytu. Jego rozwój na przestrzeni wieków zaowocował utworzeniem w Stanach Zjednoczonych w 1941 r. Instytutu Audytorów Wewnętrznych (IIA)².

K. Winiarska, Teoretyczne i praktyczne aspekty audytu wewnętrznego, Difin, Warszawa 2005, s. 11.

2 The Institute of Internal Auditors (IIA), https://www.iia.org.pl; stan na 25.04.2016 r. 
Audyt polega na obiektywnych i niezależnych działaniach, które mają za zadanie wspieranie kierownika jednostki w osiąganiu celów i założeń poprzez kontrolę zarządczą i doradztwo ${ }^{3}$. Obejmuje on szerszy obszar, a audytorzy, którzy są pracownikami przedsiębiorstwa przeprowadzają niezależne badania i dokonują oceny różnych obszarów działania, obejmujących: procesy rachunkowe, zapewnienia jakości produkcji i usług ${ }^{4}$. W standardach opracowanych przez IIA audyt został określony jako: działalność niezależna i obiektywna, której celem jest przysporzenie wartości i usprawnienie działalności operacyjnej organizacji $^{5}$. R. Moeller podkreśla, że audyt polega na systematycznej i dokonywanej w uporządkowany sposób ocenie procesów: zarządzania ryzykiem, kontroli i ładu organizacyjnego, która przyczynia się do poprawy ich działania. Pomaga organizacji osiągnać założone cele, dostarcza informacji o skuteczności procesów, jak również pełni rolę doradczą ${ }^{6}$. Niektórzy twierdzą natomiast, że działania podejmowane w ramach audytu wewnętrznego dotyczą analizy i oceny efektywności i skuteczności innych kontroli, ustanowionych przez kierownika jednostki w celu zapewnienia prawidłowego zarządzania, minimalizacji kosztów funkcjonowania jednostki oraz uzyskania jak najlepszych efektów z jej funkcjonowania.

W jsfp obowiązek prowadzenia audytu wewnętrznego został wprowadzony ustawą z dnia 27 lipca 2001 r. o zmianie ustawy o finansach publicznych z dnia 26 listopada 1998 r. Pojęcie audytu było kilkakrotnie zmieniane, a obecnie obowiązująca definicja została zawarta w artykule 272.1 ustawy z 27 sierpnia 2009 r. o finansach publicznych. Zgodnie ze wskazanym artykułem „Audyt wewnętrzny jest działalnością niezależną i obiektywną, której celem jest wspieranie ministra kierującego działem lub kierownika jednostki w realizacji celów i zadań przez systematyczną ocenę kontroli zarządczej oraz czynności doradcze" ${ }^{\text {"7 }}$. Warto podkreślić, iż definicja ta zmienia ideę audytu wewnętrznego $\mathrm{z}$ aspektu stricte finansowo-rachunkowego ${ }^{8}$

Ustawa z dnia 27 sierpnia 2009 r. o finansach publicznych, Dz.U. z 2009 r., nr 157, poz. 1240. R. Moeller, Nowoczesny audyt wewnętrzny, Wolters Kluwer business, Warszawa 2011, s. 25. The Institute of Internal Auditors (IIA), https://www.iia.org.pl; stan na 25.04.2016 r.

R. Moeller, op. cit., s. 25.

Ustawa z dnia 27 sierpnia 2009 r. o finansach publicznych.

W ustawie z dnia 30 czerwca 2005 r. o finansach publicznych pojęcie audytu wewnętrznego było zawarte w art. 48 i określane było jako: ,[...] 1) niezależne badanie systemów zarządzania i kontroli w jednostce, w tym procedur kontroli finansowej [...], w wyniku którego kierownik jednostki uzyskuje obiektywną i niezależną ocenę adekwatności, efektywności i skuteczności tych systemów; 2) czynności doradcze, w tym składanie wniosków, mające na celu usprawnienie funkcjonowania jednostki”. Por.: A. Bartoszewicz, B. Kolosowska, Audyt wewnętrzny oraz koordynacja audytu wewnętrznego w jednostkach sektora finansów publicz- 
i obejmuje swoim zasięgiem wszystkie obszary działalności jednostki, tym samym skupiając się na realizacji celów całej organizacjị.

Ustawodawca określił szereg obowiązków zmierzających do tego, aby audytor wewnętrzny miał zapewnione odpowiednie warunki pracy ${ }^{10}$. Z kolei z niezależnością audytora związana jest jego specyficzna podległość, a także ochrona stosunku pracy $^{11}$. Audyt wewnętrzny powinien być również działalnością obiektywną, która pozwala audytorowi na przeprowadzenie zadań z wiarą w efekty ich pracy, bez konieczności podporządkowywania swoich wyników badania opiniom innych osób. Efektem końcowym realizacji zadania audytowego mogą być czynności doradcze, których celem jest usprawnienie funkcjonowania jednostki. Warto podkreślić, iż przedstawione kierownikowi jednostki zalecenia czy opinie audytora, w ramach czynności doradczych, nie są jednak wiążące. Jak słusznie podkreśla A. Bartoszewicz, czynności doradcze dają jednak większą gwarancję podjęcia prawidłowej decyzji przez kierownika ${ }^{12}$.

Obowiązująca w Polsce definicja audytu wewnętrznego przybliża ją do definicji sformułowanej przez IIA, zgodnie z nią audyt wewnętrzny jest działalnością obiektywną i niezależną o charakterze zapewniającym i doradczym, która jest prowadzona w celu wniesienia do organizacji wartości dodanej i usprawnienia jej funkcjonowania ${ }^{13}$. Jednocześnie ,audyt wewnętrzny wspiera organizację w osiaganiu jej celów poprzez systematyczne i metodologiczne podejście do oceny i poprawy efektywności procesów zarządzania ryzykiem, kontroli oraz zarządzania organizacją"14.

Wzmocnienie roli audytora wewnętrznego $\mathrm{w}$ jednostce może przyczynić się do poprawy jej funkcjonowania ${ }^{15}$. Niejednokrotnie podkreśla się, iż audyt staje się

nych, w: P. Smoleń (red.), Ustawa o finansach publicznych. Komentarz, wyd. 2, C.H. Beck, Warszawa 2014, s. 1246.

9 Ibidem, s. 1247.

10 G. Golębiowski, Zmiany w audycie wewnętrznym $w$ sektorze publicznym, Ruch Prawniczy, Ekonomiczny i Socjologiczny, Rok LXXIII - Zeszyt 3-2011, s. 55.

11 Ibidem, s. 57.

12 A. Bartoszewicz, Funkcjonowanie audytu wewnętrznego w polskich samorzadach gminnych - wyniki badań, Zeszyty Teoretyczne Rachunkowości 2009/52 (108), Warszawa, s. 11.

13 E. Chojna-Duch, Audyt wewnętrzny w sektorze finansów publicznych-aktualna problematyka, Zeszyty Naukowe Uniwersytetu Szczecińskiego, Nr 718, Finanse. Rynki finansowe. Ubezpieczenia 2012/53, s. 337.

14 Standards of the Professional Practice of Internal Auditing, The Institute of Internal Auditors, Altamonte Springs 2001, s. 1.

15 P.K. Awuah, Factors determining External Auditors Reliance on Internal Audit Work in the Ghanaian Public Sector, International Journal of Marketing, Financial Services \& Management Research 2015 (November)/4 (11), s. 42-53. 
narzędziem nowoczesnego zarządzania ${ }^{16}$. Audyt, badając i oceniając działalność jsfp, powinien zatem wspierać jednostkę w osiaganiu jej celów i poprawę efektywności i skuteczności procesów zarządzania. Można stwierdzić, iż obszarem audytu wewnętrznego jest sfera zarządzania ${ }^{17}$.

Jak wynika z literatury, audyt wewnętrzny stosuje się zamiennie do kontroli wewnętrznej. W praktyce pojęcia te różnią się od siebie ustalonymi celami. Celem kontroli jest racjonalne zapewnienie, że zostaną osiągnięte kierunki działania organizacji dotyczące zgodności działań z obowiązującym prawem i regulacjami, efektywności i wydajności operacji gospodarczych oraz prawdziwości sprawozdań finansowych ${ }^{18}$. Kontrola wewnętrzna jest bowiem narzędziem, które służy wykrywaniu błędów i nieprawidłowości w konkretnych sytuacjach z określeniem odpowiedzialności. Audyt wewnętrzny koncentruje się na niedociągnięciach systemów i ich korygowaniu ${ }^{19}$. Audyt stanowi jeden z elementów kontroli wewnętrznej. Jak słusznie podkreśla H. Szymańska, audyt wewnętrzny pełni szersze funkcje niż kontrola wewnętrzna, wynika to $\mathrm{z}$ faktu, że nadzoruje on również i jej mechanizmy ${ }^{20}$. Zdaniem A.A. Adeniyi audyt jest częścią kontroli wewnętrznej wprowadzonej przez kierownika jednostki ${ }^{21}$. Powinien on wnieść wartość dodaną i udzielić zapewnienia, że system kontroli wewnętrznej działa w sposób prawidłowy, może doprowadzić do zmian w systemie kontroli ${ }^{22}$. Natomiast zdaniem B. Filipiak bez kontroli opartej na wynikach audytu trudno o sprawne i racjonalne funkcjonowanie jednostki w dłuższym okresie ${ }^{23}$.

16 T. Waściński, J. Slawińska, Audyt wewnętrzny wspomagający zarządzanie sektorem publicznym - główne problemy i propozycje usprawnień, Zeszyty Naukowe Uniwersytetu Przyrodniczo-Humanistycznego w Siedlcach, Seria Administracja i Zarządzanie 2013/97, s. 58.

17 T. Kiziukiewicz, K. Sawicki, Audyt systemu kontroli zarzadczej, w: T. Kiziukiewicz (red.), Zasady audytu wewnętrznego w sektorze finansów publicznych, Difin, Warszawa 2012, s. 293.

18 T. Waściński, J. Sławińska, op. cit., s. 58-60.

19 M. Tyrańska, Audyt wewnętrzny jako narzędzie oceny działalności przedsiębiorstw, w: E. Piwoni-Krzeszowska (red.), Współczesne problemy zarządzania organizacjami, Mfiles.pl, Kraków 2014, s. 192.

20 H. Szymańska, Ogólne zagadnienia audytu wewnętrznego, w: T. Kiziukiewicz (red.), Audyt wewnętrzny w jednostkach sektora finansów publicznych, Difin, Warszawa 2009, s. 36.

21 A.A. Adeniyi, Auditing and Investigations, Wyse Associates Limited, Lagos 2004.

22 H. Szymańska, Ogólne zagadnienia audytu wewnętrznego, w: T. Kiziukiewicz (red.), Audyt wewnętrzny w jednostkach sektora finansów publicznych, Difin Sp. z o.o., Warszawa 2007, s. 35 .

23 B. Filipiak, Audyt wewnętrzny jako podstawa kontroli i racjonalizacji gospodarki finansowej jednostek samorząu terytorialnego, w: J. Gluchowski, A. Pomorska, J. Szołno-Koguc (red.), 
Audyt ma za zadanie kontrolę i ocenę sprawności zarządzania ryzykiem przez dokonywanie regularnych przeglądów przestrzegania zasad zarządzania ryzykiem, które obowiązują $\mathrm{w}$ danej jednostce ${ }^{24}$. Ponadto powinien skupić swoje wysiłki na monitorowaniu i ocenie systemów kontroli zarządczej, a także istniejącego ładu organizacyjnego $\mathrm{w}$ jednostce, czyli procesów governance ${ }^{25}$. Jednocześnie powinien być dokonywany przegląd oraz ocena adekwatności, skuteczności oraz efektywności systemu kontroli zarządczej. Podczas badania mechanizmów kontroli zarządczej powinny zostać sformułowane wnioski dotyczące usprawnień w tym zakresie ${ }^{26}$. C.N. Van Gansberghe podkreśla, że efektywność audytu powinna być oceniana przez stopień, w jakim przyczynia się do wykazania wysokiego poziomu świadczonych usług publicznych ${ }^{27}$.

\section{Rodzaje audytu wewnętrznego}

Jednostki komercyjne mogą wprowadzić audyt stosownie do potrzeb i indywidualnych oczekiwań. Z kolei jsfp są zobowiązane wprowadzić audyt, gdy ich dochody lub wydatki bądź przychody lub rozchody osiagną wartość na poziomie 40 mln zł. Jednocześnie ustawa o finansach publicznych wymienia jednostki, w których prowadzi się audyt, a zatem odgórnie zostały one zobligowane przez ustawodawcę jako te, które muszą przeprowadzić audyt wewnętrzny, bez względu na wielkość budżetu. A. Bartoszewicz i B. Kołosowska podkreślają, że zapis ten jest swego rodzaju bodźcem zwiększającym uprawnienia kierownika jednostki do podjęcia decyzji o wprowadzeniu audytu wewnętrznego. Można domniemywać, iż chodzi o wykorzystanie audytu wewnętrznego przez jak największą liczbę

Uwarunkowania i bariery w procesie naprawy finansów publicznych, Wydawnictwo KUL, Lublin 2007, s. 226.

24 N. Stangova, A. Vigova, Financial Audit as Prediction Tool for Risk Reduction in Public Finance, Journal Studia Universitatis Babes - Bolyai Negotia 2014/2, s. 91-110.

25 E.W. Babuśka, Rola kontroli zarządczej i audytu wewnętrznego w zapewnieniu bezpiecznego systemu finansowego jednostek samorządowych, Zeszyty Naukowe PTE 2012/13, Kraków, s. 221.

26 K. Lisiecka, Audyt wewnętrzny instrumentem wspierajacym zarządzanie organizacja w sektorze publicznym, Studia Ekonomiczne Uniwersytetu Ekonomicznego w Katowicach, Nr 141, Governance - Korporacje, instytucje publiczne, sieci, Katowice 2013, s. 51-61.

27 C.N. Van Gansberghe, Internal auditing In the public sector: a consultative forum In stores up Best practices for government audit Professional In the developing nations, Internal Auditor 2005/62/4. 
podmiotów $^{28}$. W literaturze wymienia się różne rodzaje audytu ${ }^{29}$, najczęściej wskazuje się trzy jego rodzaje: finansowy, operacyjny i informacyjny ${ }^{30}$. Pierwszy polega na badaniu wiarygodności sprawozdania finansowego i sprawozdania z wykonania budżetu przez sprawdzenie przestrzegania zasad rachunkowości, zgodności zapisów w księgach rachunkowych z dowodami księgowymi itp. ${ }^{31}$ Rola audytora sprowadza się do oceny zawartości sprawozdań pod kątem dokładności i zgodności. Jednocześnie badana jest prawidłowość przeprowadzanych transakcji oraz skuteczność, oszczędność i wydajność realizowanych działań. Najważniejszą część sprawozdania z audytu stanowi opinia audytora, tj.: opis stanu faktycznego ${ }^{32}$.

Audyt operacyjny dotyczy badania wiarygodności i skuteczności systemów funkcjonujących w jednostce, a także systemu kontroli zarządczej. Przedmiotem oceny są osiagnięcia zamierzonych rezultatów do poniesionych kosztów oraz efektywność zarządzania, a zatem ocenę, w jaki sposób kierownictwo jednostki planuje swoje działania, kontroluje realizacje planów i zarządza ryzykiem. Najistotniejszą część sprawozdania stanowią zalecenia, propozycje usprawnień

28 A. Bartoszewicz, B. Kołosowska, op. cit., s. 1252.

29 K. Czerwiński wyróżnia audyt informatyczny, operacyjny, finansowy oraz audyt funduszy unijnych, K. Czerwiński, H. Grocholski, Podstawy audytu wewnętrznego, Link, Szczecin 2003, s. 215 i n.; A. Piszczyk wskazuje na dwa zasadnicze rodzaje audytu wewnętrznego, a mianowicie: audyt operacyjny, który uważa za bardziej dynamiczny, i audyt finansowy, A. Piaszczyk, Audyt wewnętrzny, Stowarzyszenie Księgowych w Polsce, Zarząd Główny, COSZ, Warszawa 2004, s. 47 i n.; K. Winiarska wymienia pięć rodzajów audytu wewnętrznego, tj.: audyt finansowy, działalności, zgodności, operacyjny oraz audyt systemów, K. Winiarska, Teoretyczne i praktyczne aspekty audytu wewnętrznego, Difin, Warszawa 2005, s. 33; D.A. Żytyniec dzieli audyt wewnętrzny na audyt finansowy i niefinansowy. W ramach audytu niefinansowego wyróżnia: audyt operacyjny, zgodności, działalności, programów oraz informatyczny. D.A. Żytyniec, Kontrola wewnętrzna i audyt wewnętrzny, w: B.R. Kuc, L. Smolak (red.), Kontrola i audyt w perspektywie europejskiej, MSWiA, Warszawa 2004. Natomiast szerszego podziału rodzajów audytu wewnętrznego dokonała E. Bielińska-Duna. E. Bielińska-Duna, Charakterystyka systemu audytu wewnętrznego, w: M. Lisiński (red.), Audyt wewnętrzny w doskonaleniu instytucji, PWE, Warszawa 2011, s. 143.

30 Por.: H. Szymańska, op. cit. (2009), s. 26 i n.; E. Babuśka, Audyt wewnętrzny w zarzadzaniu przedsiębiorstwem, w: K. Winiarska (red.), Controlling $i$ audyt w usprawnianiu zarządzania, US w Szczecinie, Szczecin 2005, s. 275-280.

31 A. Herdan, Przestanki $i$ warunki wdrożenia audytu wewnętrznego w sektorze finansów publicznych, Zeszyty Naukowe Wyższej Szkoły Ekonomicznej w Bochni 2005/3, s. 28.

32 T. Waściński, J. Sławińska, op. cit., s. 61; H. Szymańska, Ogólne zagadnienia audytu wewnętrznego, w: T. Kiziukiewicz (red.), Zasady audytu wewnętrznego w sektorze finansów publicznych, Difin, Warszawa 2012, s. 27 i n.; K. Czerwiński, Audyt wewnętrzny, InfoAudit, Warszawa 2005. 
lub rekomendacje. Według M.C. da Costa Marques audyt operacyjny przyjmuje znaczącą rolę w kontekście nowego zarządzania publicznego ${ }^{33}$.

Audyt informacyjny prowadzony jest w celu określenia, czy istniejące zabezpieczenia systemów informatycznych, procesy, procedury systemu zarządzania bezpieczeństwem informacji są zgodne z obowiązującymi regulacjami prawnymi, zidentyfikowanymi wymaganiami bezpieczeństwa informacji, oczekiwaniami i czy zostały prawidłowo wdrożone oraz utrzymywane ${ }^{34}$.

\section{Metodologia badania}

Do udziału w badaniu zaproszono 100 największych spółek w Polsce z listy największych polskich firm, ujętych w zestawieniu Lista 500 opracowanej przez tygodnik Rzeczpospolita w 2015 r., oraz wybrane jsfp (Urzędy Wojewódzkie, Marszałkowskie oraz jednostki samorządu terytorialnego z województw: kujawsko-pomorskiego i pomorskiego ${ }^{35}$. Dobór próby nie miał charakteru doboru losowego. Autorki zdecydowały się na wybór celowy, ukierunkowany na największe jednostki gospodarcze, posiadające wielopoziomową strukturę organizacyjną. Jednocześnie autorki artykułu zdecydowały się na przeprowadzenie wspólnej analizy obu grup jednostek, ze względu na to, iż wstępna analiza każdej $\mathrm{z}$ w/w grup została już wcześniej opublikowana indywidualnie.

Badanie zostało przeprowadzone $\mathrm{z}$ wykorzystaniem metody ankiety pocztowej w okresie od maja do sierpnia 2015 r. Przesłane do respondentów kwestionariusze ankietowe składały się z dwóch części:

- pierwsza miała dostarczyć informacji o badanych podmiotach;

- druga obejmowała pytania dotyczące procesu wdrożenia, zakresu prac i spo-

sobów dokumentacji oraz korzyści wynikających z wprowadzenia audytu wewnętrznego.

Pytania zawarte w kwestionariuszu badawczym miały mieszany charakter, wymagały udzielenia odpowiedzi tak lub nie. W wielu przypadkach respondent był poproszony o wybór jednego lub kilku przedstawionych wariantów, mógł też wpisać własne propozycje i spostrzeżenia.

33 M.C. Da Costa Marques, The Role of Auditing In the Public Sector, http://www.mngt.waikato. ac.nz/ejrot/cmsconference/2005/proceedings/criticalaccounting/DaConceicao.pdf; stan na 25.04.2016 r.

34 T. Waściński, J. Sławińska, op. cit., s. 62.

35 Pozostałe województwa zostaną zbadane w drugiej turze grantu badawczego w latach 2016/2017. 


\subsection{Charakterystyka badanej grupy}

Przygotowane kwestionariusze zostały wysłane do 100 spółek i 250 wybranych jsfp. Wypełnione kwestionariusze odesłało 41 spółek, z których 38 stosowało audyt i uwzględniono je w badaniu, z kolei od jsfp otrzymano 173 kwestionariusze, z których 107 jednostek wdrożyło procedury audytu.

Podmioty gospodarcze, które zwróciły kwestionariusz, prowadziły działalność handlowo-usługową (44,74\%) i wchodziły w skład grupy kapitałowej (86,84\%). Z udziałem kapitału zagranicznego było 55,26\% badanych podmiotów, natomiast w ponad połowie $\mathrm{z}$ badanych podmiotów $(55,26 \%)$ wielkość zatrudnienia wynosiła od 51 do 250 pracowników. Blisko połowa z respondentów $(47,37 \%)$ za 2014 r. uzyskała przychody powyżej $500 \mathrm{mln}$ PLN.

Z kolei badane jsfp wskazały na zróżnicowaną ich wielkość zarówno pod względem liczby zatrudnionych, jak i uzyskiwanych przychodów/wpływów. Najwięcej jednostek zatrudniało od 20-50 osób (48\%), na drugim miejscu znalazły się jednostki zatrudniające od 51-250 osób (30\%). Jedynie 3\% stanowiły jednostki małe, zatrudniające do 20 osób $^{36}$. W spółkach wśród respondentów przeważali audytorzy wewnętrzni, a w jsfp byli to: sekretarze jednostek $(33,6 \%)$, audytorzy wewnętrzni (20,8\%), skarbnicy (17,3\%). W 9,8\% przypadków nie wskazano osoby, która wypełniała ankietę.

\section{Wdrażanie i wykorzystanie audytu wewnętrznego w badanych jednostkach}

Biorąc pod uwagę wyniki wśród badanych jsfp jedynie 107 jednostek (62\%) wdrożyło procedury audytu, a 7 respondentów stwierdziło, że planuje to zrobić w najbliższym czasie. Natomiast spośród badanych spółek wypełnione kwestionariusze odesłało 41 spółek, z których 38 stosowało audyt, i uwzględniono je w badaniu.

36 Częściowo wyniki badania pilotażowego w wybranych jednostkach sektora finansów publicznych zostały opublikowane w książce: J. Ciak, M. Gotowska, A. Goździewska, A. Jakubczak, E. Korelewska, A. Michalska, A. Morawska, G. Voss, Z. Wyszkowska, Współczesne wyzwania gospodarki, UTP, Bydgoszcz 2016, s. 109-126; J.M. Ciak, Experiences of Selected Public Finance Sector Entities Gained on Internal Audit Functioning in Poland - Research Findings, Journal of Scientific Research and Report 2016/10 (6), s. 1-9. Z kolei część wyników badania w spółkach z Listy 500 przedstawiono w publikacji: G. Voss, Rola i zadania audytu wewnętrznego w zarządzaniu przedsiębiorstwem, Technika Transportu Szynowego 2015/12, s. $1600-1603$. 
WYKRES 1: Liczba podmiotów, które wprowadziły audyt wewnętrzny

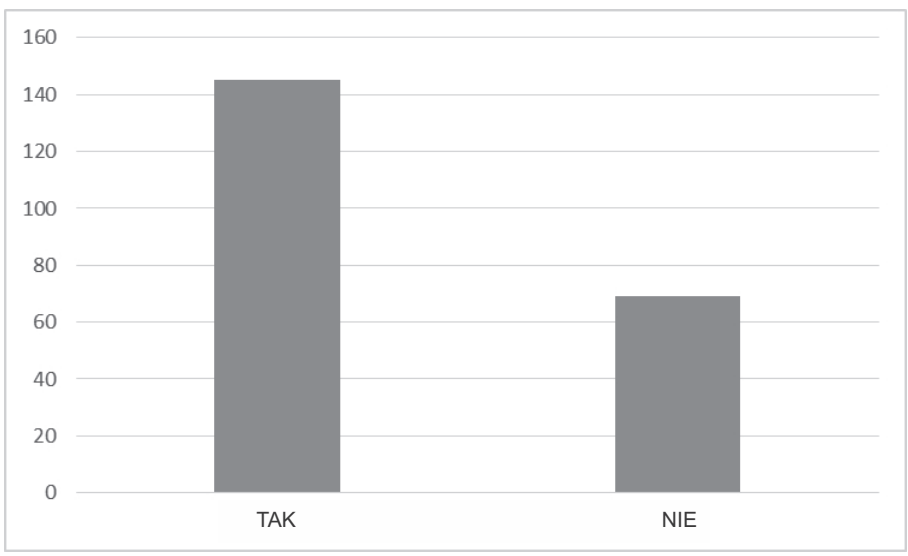

Ź r ó d ło: wyniki badań własnych.

WYKRES 2: Przyczyny wdrażania audytu wewnętrznego

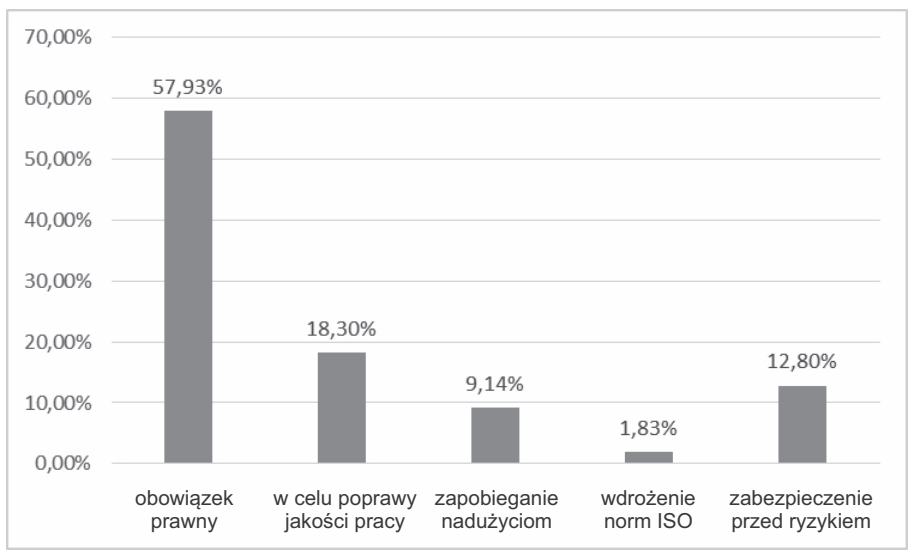

Źr ó d ło: wyniki badań własnych.

Wśród respondentów 66 podmiotów zaliczanych do jsfp i 3 podmioty z sektora prywatnego nie wprowadziło audytu wewnętrznego. Wynikało to z nieosiągnięcia wskazanego w ustawie o finansach publicznych poziomu planowanych wpływów publicznych do ich budżetów. Pozostałe jednostki za podstawę i przyczynę wdrożenia audytu wskazywało obowiązek prawny $(57,93 \%)$ (wykres 2 ). 
Na pytanie o problemy z wdrożeniem audytu wskazywano najczęściej na konieczność zatrudnienia audytora, co zwiększa koszty funkcjonowania jednostki, narzucenie wypełnienia obowiązku prawnego czy ponoszenie dodatkowych kosztów finansowych związanych z wdrożeniem i utrzymaniem certyfikatu normy ISO 9001.

Jednostki wskazywały, że obszarami, które najczęściej objęte są audytem, to działalność finansowa $(37,50 \%)$, operacyjna $(30,83 \%)$ i informatyczna $(30,56 \%)^{37}$ (wykres 3).

WYKRES 3: Obszary objęte audytem w badanych jednostkach

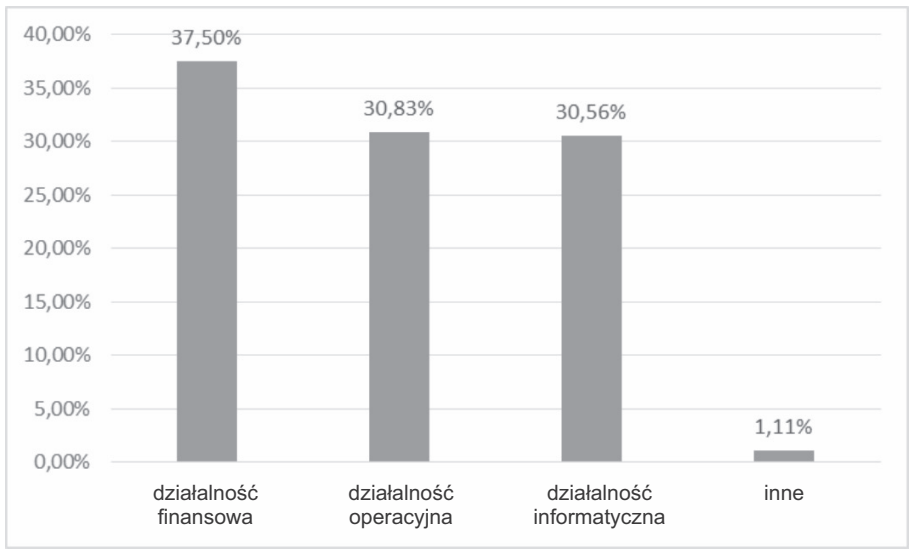

Ź ró d ło: wyniki badań własnych.

Na pytanie o efekty wdrożenia i wykorzystania procedur oraz wyniki audytu wewnętrznego, a w szczególności o poprawę efektywności i skuteczności zarządzania badane jednostki w 92,41\% odpowiedziały tak.

Warto podkreślić, że od momentu pojawienia się instytucji audytu wewnętrznego stała się ona, poprzez swoje usytuowanie organizacyjne oraz specyficzne metody działania, szczególną częścią systemu nadzoru nad gospodarką finansową sektora finansów publicznych i sektora prywatnego. Dlatego kierownicy tych jednostek powinni zdawać sobie sprawę, że silna pozycja audytu w systemie nadzoru ich jednostki ma znaczenie dla kontroli jej działań oraz celu i środków wykorzystywanych w działaniu ${ }^{38}$.

37 Niektóre jednostki wskazywały na inne dziedziny, które stanowiły obszar badania audytowego, np.: Programy unijne (RPO, POKL, PROW, PO Ryby), zamówienia publiczne, funkcjonowanie systemu kontroli zarządczej czy ocena gospodarności (audyt efektywnościowy).

38 P. Soltyk, Audyt wewnętrzny w samorządach, Wspólnota.org.pl, Gospodarka i Finanse 2008/37. 
Zgodnie z zapisami ustawy do dokumentów, na bazie których można prowadzić audyt, zalicza się:

- księgę audytu (z opisem procedur);

- plan i harmonogram prac audytorów;

- kodeks dobrych praktyk;

- kodeks etyki audytora.

Ankietowani wskazywali, iż $\mathrm{w}$ ich jednostkach audyt realizowany jest w oparciu o: plan i harmonogram prac audytorów wewnętrznych $(37,26 \%)$, księgę audytu (33,08\%), kodeks etyki audytora oraz kodeks dobrych praktyk $(14,45 \%)$ (wykres 4$)$.

WYKRES 4: Dokumenty stanowiące podstawę przeprowadzenia audytu wewnętrznego w badanych jednostkach

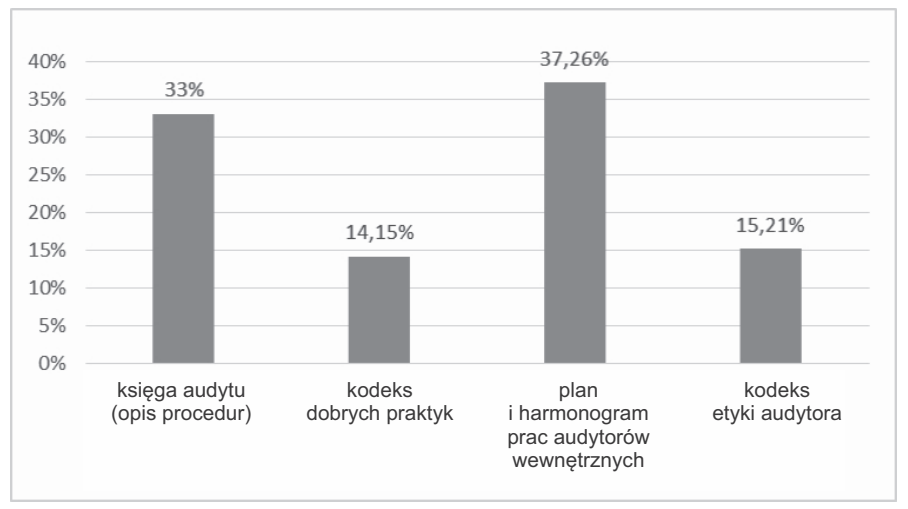

Ź r ó d ło: wyniki badań własnych.

Jednocześnie zakres prac audytu realizowany jest w oparciu o plan audytu $(47,59 \%)$, plan audytu po uwzględnieniu potrzeb $(40,00 \%)$, o potrzeby pracy związane z wprowadzeniem i utrzymaniem norm ISO (2,07\%) i innych dokumentów $(10,43 \%)$, tj.: harmonogramu prac audytora wewnętrznego, zarządzenia kierownika jednostki dotyczące audytu lub kontroli zarządczej bądź księgi audytu $^{39}$ (wykres 5).

39 Były też dodatkowe odpowiedzi wskazujące na inne dokumenty, tj.: Regulamin audytu wewnętrznego, Standardy audytu wewnętrznego czy Rozporządzenie Ministra Finansów w sprawie przeprowadzenia i udokumentowania audytu. 
WYKRES 5: Podstawy zakresu prac audytu wewnętrznego

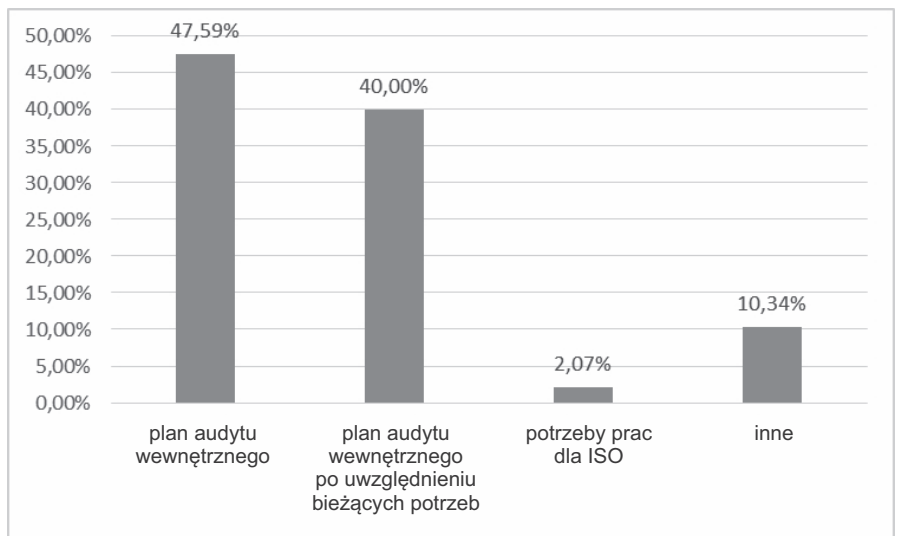

Ź ródło: wyniki badań własnych.

W myśl art. 275 ustawy o finansach publicznych audyt wewnętrzny może być prowadzony przez:

- audytora wewnętrznego zatrudnionego w jednostce,

- usługodawcę niezatrudnionego w jednostce.

Jedną z przyczyn dokonywania wyboru są względy finansowe. Możliwość wyboru stanowi punkt wyjścia do rozwiązania problemu braku kadry audytorskiej w Polsce ${ }^{40}$. Badane jednostki korzystały zarówno z usług zewnętrznego audytora (usługodawcę) (31,92\%), jak i wewnętrznego (48,08\%), przy czym część z badanych jednostek wskazywała na kierownika komórki audytu $(25,53 \%)$ lub też audytorów w zakresie poszczególnych rodzajów audytu (wykres 6).

Praktyką w zakresie wdrażania audytu jest organizowanie spotkań z kierownikami jednostek i działów, które były objęte w danym roku audytem, celem omówienia zadań i procedur. Większa część ankietowanych organizuje takie spotkania $(56,74 \%)$. Wśród tych jednostek najczęściej na spotkaniach omawiane są wyniki audytu z poprzedniego roku $(36,11 \%)$ oraz plan na bieżący rok $(35,42 \%)$, omówienie zmian w procedurach audytu $(15,97 \%)$ i ustalenie harmonogramu na bieżący rok (12,50\%) (wykres 7).

40 A. Bartoszewicz, B. Kolosowska, op. cit., s. 1253. 
WYKRES 6: Podmiot realizujacy audyt w badanych jednostkach

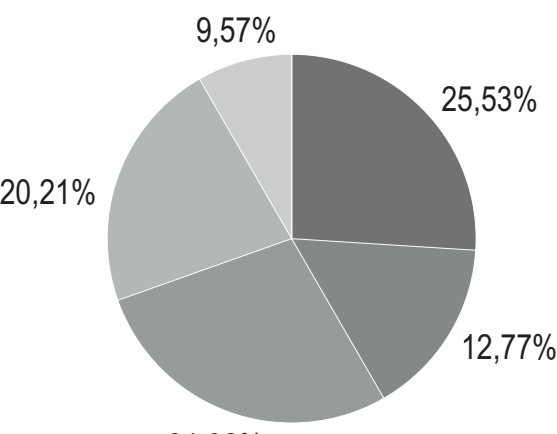

$31,92 \%$

Kierownik komórki audytowej

Audytor wewnętrzny ds. audytu operacyjnego

Audytor zewnętrzny

Audytor wewnętrzny ds. audytu finansowego

Audytor wewnętrzny ds. audytu informatycznego

Źr ó d ło: wyniki badań własnych.

WYKRES 7: Tematy najczęściej omawiane podczas spotkań audytora z kierownikami działów

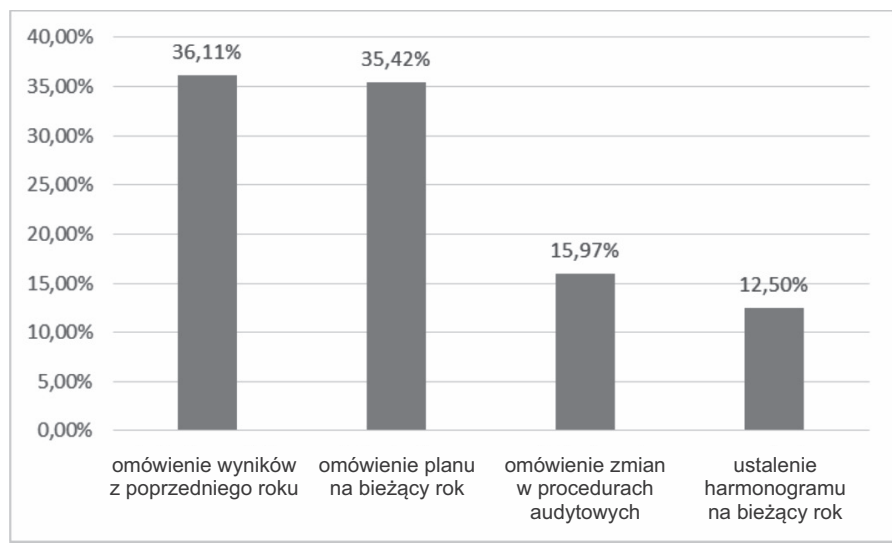

Ź r ó d ło: wyniki badań własnych.

Przeprowadzenie audytu wymaga poinformowania pracowników działów, w których będzie on realizowany. Większa część badanych jednostek $(82,48 \%)$ 
potwierdziła, iż z wyprzedzeniem informuje swoich pracowników o tym fakcie. Audytor, każdorazowo przystępując do przeprowadzenia audytu, informuje o celu i zakresie danego zadania audytowego (78,48\%). Jednocześnie badane jednostki wskazywały, że zarówno wdrożenie, jak i przeprowadzenie audytu powodowało $(89,20 \%)$ dodatkowe obciążenie dla pracowników, a w praktyce pracownicy mieli sposobność na bieżąco zgłaszać swoje sugestie w celu usprawnienia procedur i prac audytowych $(91,22 \%)$.

Audyt powinien wspierać kierownika jednostki w realizacji celów i zadań. Ankietowane jednostki wskazywały główne na kierownika jednostki $(49,81 \%)$ jako tego, który wykorzystuje otrzymane wyniki audytu wewnętrznego, natomiast $5,66 \%$ badanych wymieniało kierowników działów (wykres 8).

WYKRES 8: Osoby najczęściej korzystające z wyników audytu wewnętrznego

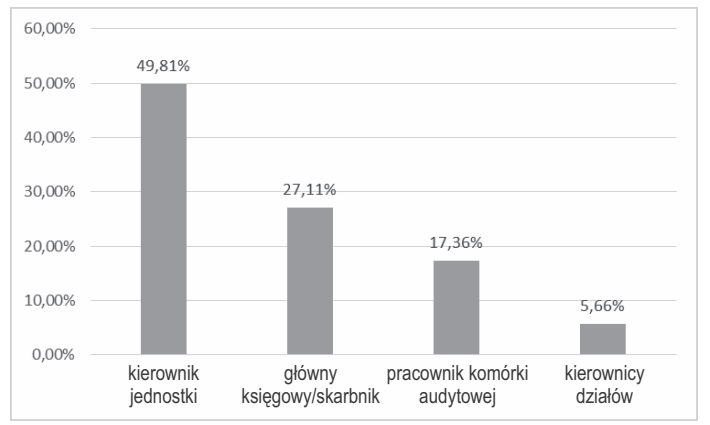

Źr ód ło: wyniki badań własnych.

Zarówno audyt, jak i wyniki zawarte w sprawozdaniu powinny przynieść wartość dodaną jednostce. Większość $\mathrm{z}$ ankietowanych uznała informacje zawarte w sprawozdaniu z audytu za informacje o wysokim stopniu przydatności (49,65\%). W literaturze niejednokrotnie podkreśla się, że jednostki objęte audytem niekiedy nie korzystają ze sprawozdań audytora. W jednostkach objętych badaniem tylko niewielki odsetek (1,38\%) z nich nie korzysta (wykres 9).

Wskazane informacje o wykorzystywaniu wniosków i sugestii audytora przez kierowników jednostek potwierdzają wyniki zawarte w odpowiedziach kolejnego pytania. 44,45\% ankietowanych jednoznacznie stwierdziło, że otrzymane wyniki sprawozdania $\mathrm{z}$ audytu przyczyniły się do poprawy funkcjonowania badanych komórek i 53,47\% wskazały na częściową poprawę. Wśród odpowiedzi wskazywano na wprowadzanie nowych lub poprawę istniejących rozwiązań w badanych komórkach, eliminację nieprawidłowości czy zwiększenie efektywności ich 
działania. Wskazywano również na to, iż audyt daje możliwość wyeliminowania słabości kontroli zarządczej w funkcjonowaniu komórek i poszczególnych jednostek. Wśród odpowiedzi negatywnych (2,08\%) można było znaleźć stwierdzenia: o podmiotowym traktowaniu audytu, uznawaniu go za ,zło konieczne w jednostce”, braku przełożenia wydawanych zaleceń na jakość pracy czy oszczędności w działalności jednostki i słabości w jakości prowadzonego audytu wewnętrznego.

WYKRES 9: Przydatność informacji zawartych $w$ sprawozdaniu z audytu dla dalszego funkcjonowania jednostki

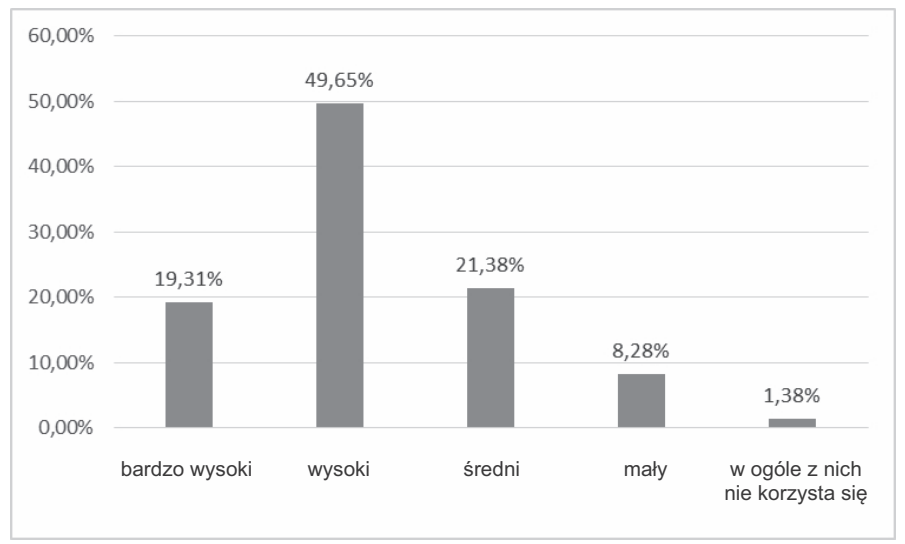

Źr ó d ło: wyniki badań własnych.

Biorąc od uwagę ogólną ocenę instytucji audytu wewnętrznego, $85 \%$ badanych uznało ją za przydatna. Nie miało zdania na ten temat $9 \%$ badanych, z kolei $6 \%$ jednostek uważało tę instytucję za nieprzydatną w ich organizacji.

Większość ankietowanych nie miała żadnych spostrzeżeń ani sugestii w związku z funkcjonowaniem komórki audytu w ich jednostce (77,6\%). Pozostali wskazywali głównie na to, że nie zawsze kadra najwyższego szczebla umie wykorzystać pozyskane informacje z audytu. Aby audyt spełniał swe zadania, konieczne są zatem rozwiązania prawne narzucające obowiązkowe istnienie komórki audytu (wyodrębnienie tej komórki z komórki kontroli i kontroli wewnętrznej ${ }^{41}$ ). Wskazywano też na dużą presję na objęcie audytem wszystkich obszarów, bez względu na ich znaczenie i ryzyko.

41 Jak wynika z przeprowadzonego przez Ministerstwo Finansów w 2015 r. badania, pomimo wyodrębnienia w większości badanych jednostek komórki audytu w strukturze organizacyjnej, następuje łączenie tych komórek z innymi komórkami. Autorzy raportu domniemają, że może to wynikać ze względów praktycznych, a mianowicie z dążenia do zmniejszania liczby 


\section{Zakończenie}

Audyt wewnętrzny definiowany jest jako obiektywna i niezależna działalność, której celem jest wspieranie kierownika danej jednostki w realizacji celów i zadań. Audytor wewnętrzny powinien dostarczyć kierownikowi jednostki informacji, które zapobiegną materializacji ryzyk, na które jest ona narażona, oraz przedstawić usprawnienia systemowe, które przyczynią się do poprawy efektywności działania tej jednostki. Opracowanie odpowiednich procedur przeprowadzenia audytu pozwala na eliminację nieprawidłowości w danej jednostce. Wyniki badań w zakresie wdrażania i funkcjonowania audytu wewnętrznego w wybranych jednostkach wykazały, że organizacja i działalność audytu w większości przypadków była zgodna z przepisami prawa, a przyjęte rozwiązania umożliwiały generalnie niezależność działań audytorom. Badane jednostki były i są zainteresowane instytucją audytu wewnętrznego. Większość jednostek nie miała znaczących problemów z wdrożeniem audytu. Pozostałe jednostki, jako problem, wskazywały najczęściej na konieczność zatrudnienia audytora, narzucenie wypełnienia obowiązku prawnego czy ponoszenie dodatkowych kosztów finansowych związanych z wdrożeniem i utrzymaniem certyfikatu normy ISO 9001.

U większości badanych podmiotów przedmiotem audytu była i jest działalność finansowa, operacyjna i informacyjna, a audyt przeprowadza audytor wewnętrzny zatrudniony $\mathrm{w}$ tej jednostce. Najczęściej z informacji zawartych w sprawozdaniach z przeprowadzonego audytu korzystał kierownik, główny księgowy i skarbnik. Uzyskane wyniki po dokonaniu zmian w jednostce przyczyniały się do poprawy jej funkcjonowania. Ankietowani wskazywali też na słabą skuteczność i efektywność audytu. Nie zawsze też kadra najwyższego szczebla umiała wykorzystać pozyskane z audytu informacje. Ponadto zbyt duża presja na objęcie audytem wszystkich procesów wydłużała cykl audytu i częstotliwość audytowania najistotniejszych obszarów, z punktu widzenia wystąpienia tam wysokiego ryzyka nieprawidłowości. Przeprowadzone badanie pozwoliło na uzyskanie odpowiedzi na pytania zawarte we wstępie artykułu.

Jak wskazano we wstępie badanie ankietowe zostało przeprowadzone tylko na części wybranych jednostek sektora finansów publicznych, stanowiąc badanie

samodzielnych komórek i stanowisk kierowniczych. Może to również wynikać z postrzegania działalności kontrolnej i audytowej jako działalności, które mają podobny charakter. Szerzej: Ocena funkcjonowania audytu wewnętrznego w jednostkach sektora finansów publicznych, Ministerstwo Finansów, Warszawa, grudzień 2015, s. 7. 
pilotażowe. Autorki wyrażają nadzieję, że kolejne badania w tym zakresie potwierdzą lub też poszerzą wnioski i spostrzeżenia w tej kwestii, pozwolą na szerszą identyfikację problemów i korzyści związanych z funkcjonowaniem audytu.

\section{Bibliografia}

\section{Akty prawne}

Ustawa z dnia 27 sierpnia 2009 r. o finansach publicznych, Dz.U. z 2009 r., nr 157, poz. 1240.

\section{Opracowania}

Awuah Paul K., Factors determining External Auditors Reliance on Internal Audit Work in the Ghanaian Public Sector, International Journal of Marketing, Financial Services \& Management Research 2015 (November)/4 (11).

Adeniyi Akinola A., Auditing and Investigations, Wyse Associates Limited, Lagos 2004.

Babuśka Ewa W., Rola kontroli zarzadczej $i$ audytu wewnętrznego w zapewnieniu bezpiecznego systemu finansowego jednostek samorzadowych, Zeszyty Naukowe PTE 2012/13, Kraków.

Babuśka Ewa, Audyt wewnętrzny w zarządzaniu przedsiębiorstwem, w: Kazimiera Winiarska (red.), Controlling i audyt w usprawnianiu zarządzania, US w Szczecinie, Szczecin 2005.

Bartoszewicz Anna, Funkcjonowanie audytu wewnętrznego w polskich samorzadach gminnych - wyniki badań, Zeszyty Teoretyczne Rachunkowości 2009/52 (108), Warszawa.

Bartoszewicz Anna, Kołosowska Bożena, Audyt wewnętrzny oraz koordynacja audytu wewnętrznego w jednostkach sektora finansów publicznych, w: Paweł Smoleń (red.), Ustawa o finansach publicznych. Komentarz, wyd. 2, C.H. Beck, Warszawa 2014.

Bielińska-Duna Elżbieta, Charakterystyka systemu audytu wewnętrznego, w: Marek Lisiński (red.), Audyt wewnętrzny $w$ doskonaleniu instytucji, PWE, Warszawa 2011.

Ciak Jolanta, Gotowska Małgorzata, Goździewska-Nowicka Agnieszka, Jakubczak Anna, Koreleska Ewa, Michalska Anna, Murawska Anna, Voss Grażyna, Wyszkowska Zofia, Wspótczesne wyzwania gospodarki, UTP, Bydgoszcz 2016.

Ciak Jolanta M., Experiences of Selected Public Finance Sector Entities Gained on Internal Audit Functioning In Poland - Research Findings, Journal of Scientific Research and Report 2016/10 (6).

Chojna-Duch Elżbieta, Audyt wewnętrzny w sektorze finansów publicznych - aktualna problematyka, Zeszyty Naukowe Uniwersytetu Szczecińskiego, Nr 718, Finanse. Rynki Finansowe. Ubezpieczenia 2012/53.

Czerwiński Krzysztof, Grocholski Henryk, Podstawy audytu wewnętrznego, Link, Szczecin 2003.

Czerwiński Krzysztof, Audyt wewnętrzny, InfoAudit, Warszawa 2005.

Filipiak Beata, Audyt wewnętrzny jako podstawa kontroli i racjonalizacji gospodarki finansowej jednostek samorzadu terytorialnego, w: Jan Głuchowski, Alicja Pomorska, Jolanta Szołno-Koguc (red.), Uwarunkowania i bariery w procesie naprawy finansów publicznych, Wydawnictwo KUL, Lublin 2007.

Gołębiowski Grzegorz, Zmiany w audycie wewnętrznym w sektorze publicznym, Ruch Prawniczy, Ekonomiczny i Socjologiczny, Rok LXXIII - Zeszyt 3-2011. 
Herdan Agnieszka, Przesłanki $i$ warunki wdrożenia audytu wewnętrznego w sektorze finansów publicznych, Zeszyty Naukowe Wyższej Szkoły Ekonomicznej w Bochni 2005/3.

Kiziukiewicz Teresa, Sawicki Kazimierz, Audyt systemu kontroli zarządczej, w: Teresa Kiziukiewicz (red.), Zasady audytu wewnętrznego w sektorze finansów publicznych, Difin, Warszawa 2012.

Lisiecka Krystyna, Audyt wewnętrzny instrumentem wspierajacym zarządzanie organizacja w sektorze publicznym, Studia Ekonomiczne Uniwersytetu Ekonomicznego w Katowicach, $\mathrm{Nr}$ 141, Governance - Korporacje, instytucje publiczne, sieci, Katowice 2013.

Moeller Robert, Nowoczesny audyt wewnętrzny, Wolters Kluwer business, Warszawa 2011.

Ocena funkcjonowania audytu wewnętrznego w jednostkach sektora finansów publicznych, Ministerstwo Finansów, Warszawa, grudzień 2015.

Piaszczyk Artur, Audyt wewnętrzny, Stowarzyszenie Księgowych w Polsce, Zarząd Główny, COSZ, Warszawa 2004.

Soltyk Piotr, Audyt wewnętrzny w samorzadach, Wspólnota.org.pl, Gospodarka i Finanse 2008/37.

Standards of the Professional Practice of Internal Auditing, The Institute of Internal Auditors, Altamonte Springs 2001.

Stangova Nora, Vigova Agnesa, Financial Audit as Prediction Tool for Risk Reduction in Public Finance, Journal Studia Universitatis Babes - Bolyai Negotia 2014/2.

Szymańska Halina, Ogólne zagadnienia audytu wewnętrznego, w: Teresa Kiziukiewicz (red.), Audyt wewnętrzny w jednostkach sektora finansów publicznych, Difin Sp. z o.o., Warszawa 2007.

Szymańska Halina, Ogólne zagadnienia audytu wewnętrznego, w: Teresa Kiziukiewicz (red.), Audyt wewnętrzny w jednostkach sektora finansów publicznych, Difin Sp. z o.o., Warszawa 2009.

Szymańska Halina, Ogólne zagadnienia audytu wewnętrznego, w: Teresa Kiziukiewicz (red.), Zasady audytu wewnętrznego w sektorze finansów publicznych, Difin, Warszawa 2012.

Tyrańska Magdalena, Audyt wewnętrzny, jako narzędzie oceny działalności przedsiębiorstw, w: Estera Piwoni-Krzeszowska, Tomasz Małkus (red.), Współczesne problemy zarządzania organizacjami, Mfiles.pl, Kraków 2014.

Van Gansberghe Cecilia Nordin, Internal auditing in the public sector: a consulttive forum in stores up best practices for government audit Professional in the developing nations, Internal Auditor 2005/62/4.

Voss Grażyna, Rola i zadania audytu wewnętrznego w zarzadzaniu przedsiębiorstwem, Technika Transportu Szynowego 2015/12.

Waściński Tadeusz, Sławińska Joanna, Audyt wewnętrzny wspomagający zarządzanie sektorem publicznym - główne problemy i propozycje usprawnień, Zeszyty Naukowe Uniwersytetu Przyrodniczo-Humanistycznego w Siedlcach, Seria Administracja i Zarządzanie 2013/97.

Winiarska Kazimiera, Teoretyczne i praktyczne aspekty audytu wewnętrznego, Difin, Warszawa 2005.

Żytyniec Dorota, Kontrola wewnętrzna i audyt wewnętrzny, w: Bolesław R. Kuc, Leszek Smolak, Kontrola i audyt w perspektywie europejskiej, MSWiA, Warszawa 2004.

\section{Strony internetowe}

Da Costa Marques M.C., The Role of Auditing In the Public Sector, http:/www.mngt.waikato. ac.nz/ejrot/ cmsconference/2005/proceedings/criticalaccounting/DaConceicao.pdf; stan na 25.04.2016 r.

The Institute of Internal Auditors (IIA), https://www.iia.org.pl; stan na dzień 25.04.2016 r. 
Jolanta M. CIAK, Grażyna VOSS

\title{
THE ROLE OF INTERNAL AUDIT IN THE PUBLIC AND PRIVATE SECTORS - THE RESULTS OF RESEARCH INTO THE PROBLEMS OF IMPLEMENTATION AND BENEFITS OF THE USE OF INTERNAL AUDIT
}

\author{
( Sum mary)
}

Internal audit is an independent and objective activity whose aim is to add value and improve operational activity of an organisation. Its role comes down to systematic and disciplined evaluation of risk management processes, of control and organisational governance. The final effect should be improvement of their activity. The article discusses the first part of research on internal audit functioning in selected units of public finance sector and in entities among the biggest limited companies in Poland.

The aim of the article is to present the types of internal audit, to discuss internal audit as an instrument improving management of an entity and to indicate problems of implementing and benefits of its use.

The results of the conducted research in the area of implementing and functioning of internal audit in selected entities indicated that the organization and operating of internal audit in most cases conformed with the relevant law, and the measures adopted generally enabled auditors to act independently. The analysed entities were and still are interested in internal auditing. In their opinion, the implementation of recommendations of an internal auditor improves the efficiency of their activities and the conduction of activities verifying the implementation by an auditor indicates the correctness of his observations. However, the respondents also indicated in some cases low efficiency and effectiveness of audit.

Keywords: internal audit; public sector entities; list 500; internal control 